\title{
Regulating credit rating agencies in the European Union: where might it lead?
}

\author{
by Harry McVea
}

\section{INTRODUCTION}

Credit Rating Agencies (CRAs) - the three largest of which are Standard and Poor's, Moody's, and Fitch - provide standardised, easy to understand, and supposedly independent (third party) assessments of credit quality. However, the use (and abuse) of credit ratings for assetbacked securities generally, as well as those collateralized by and associated with sub-prime residential mortgages in particular, has today cast a long shadow over the ability of these "gatekeepers" to provide reliable signals upon which parties - investors, financial institutions and regulators can make informed decisions.

The aim of this short article is to provide a critical appraisal of CRAs in the light of their role in the subprime mortgage debacle and to describe and assess the EU's recent attempts to regulate them more strictly. The material is structured around three key questions:

- firstly, given past criticism, how was it that CRAs came to exert such significant and, seemingly, unchecked private power?

- secondly, in the context of the recent crisis, how did CRAs become implicated?

- thirdly, in the light of shortcomings in CRA operations and assessments, what has the EU's response been and to what effect?

\section{QUESTION I}

GIVEN PAST CRITICISM, HOW WAS IT THAT CRAS CAME TO EXERT SUCH SIGNIFICANT AND, SEEMINGLY, UNCHECKED PRIVATE POWER?

Significantly, even before the recent crisis, the role CRAs had been the subject of intense scrutiny and long running criticism. This criticism centred, for example, on claims that:

- ratings were compromised by acute conflicts of interest;

- CRAs provided little informational value, especially for more complex asset-backed securities, where

downgrades tended to be reactive rather than proactive; and
- CRAs were largely unaccountable given the market power they exerted.

Perhaps the most vivid illustration of CRA failures in the pre-crisis era was in relation to Enron, where - somewhat remarkably - Enron's credit rating was only downgraded a few days before the company filed for bankruptcy, despite the fact that its difficulties were widely known.

What is clear today, is that this past scrutiny and criticism has continued to intensify in the wake of the recent financial crisis where, to begin with, CRAs were blamed for causing the crisis; and now - as a result of a wave of sovereign debt downgrades - they are being criticised for preventing nation states from extricating themselves from the economic problems which the crisis has caused. What is more, the current scrutiny which attaches to CRAs the world over, follows recent attempts both nationally (eg in the US where many of the leading CRAs are headquartered), and internationally (eg through the selfregulatory efforts of the International Organization of Securities Commissions (IOSCO)) aimed at addressing some of the pre-crisis problems associated with CRA operations.

The emergence of CRAs as a dominant force in financial markets is often said to be associated with their so-called "reputation capital." CRAs are said to "decode" risks, the quality of which can be relied upon because CRAs have a reputation to maintain which they would not want to jeopardize through shoddy work. CRA assessments of credit quality help investors to better understand the risks they face. And the standardised assessments utilised by CRAs (based on an alphabetical system, with AAA typically representing the highest grade) can help investors around the world to establish relatively simplified investment parameters in investment mandates.

Issuers of securities actively seek out CRA ratings - and pay handsomely for their services - in the hope that a good rating will lower their cost of capital and provide them with a competitive advantage with regard to other issuers.

But, in truth, the increased influence of CRAs as a force in global financial markets is not so much linked to good 
reputations based on the informational content of their credit ratings (ie their "reputational capital"). Rather, it is associated with the fact that regulators - on a global scale - have sought to harness the claimed informational value associated with CRA ratings by "enrolling" them, in effect, as "surrogate regulators" and by using their ratings as a proxy for regulatory assessments.

More specifically, regulators have sought to devise frameworks which enable regulated entities - particularly banks - to rely on external credit ratings to help calculate risk exposures and thus meet capital adequacy requirements (the so-called "standardised approach"). For example, the Basel Committee on Banking Supervision (an international forum for the world's leading banking supervisors) permits banks to use ratings from certain accredited CRAs to determine minimum credit risk capital requirements under Pillar I of the Basel Capital Accord (Basel II). In the EU, these "soft law" principles have also been embedded in legal rules as part of the EU's Capital Requirements Directive 2006/48/EC (CRD) (applicable to all deposit-takers - except credit unions and certain types of investment firms) which, inter alia, implements Basel II.

Consequently, in Europe, a CRA's credit assessments can, under certain circumstances, be used for capital requirement purposes in determining the risk weighing associated with a range of assets held by banks on their balance sheets. In the US, the Securities and Exchange Commission (SEC) performs a similar service in relation to CRAs (or "nationally recognised statistical rating organisations" (NRSROs), as they are officially known in the US).

In effect, because of this international regulatory consensus, regulators have vested CRAs with a power to sell regulatory licences. That is to say, regulators have given CRAs power to determine who is compliant with regulatory rules.

However, the recent and unfolding link between CRAs and the implosion of the market for structured products generally, and the subprime mortgage market in particular, has reignited interest in the operation and accountability of CRAs and in their continuing role as key agencies in which regulators (and, indeed, investors) can place their faith. The effect of this interest has been to cast a long shadow over their alleged reputational capital (the putative source of their legitimising power) and the exact nature of their future operations. More specifically, for the purposes of this article, it has lead to the enactment of EU legislation, in the form of a Regulation, regulating the operation of CRAs within the EU (as well as more recent additional EU proposals) which are likely to have important implications for the operations not only of CRAs in Europe, but for the use of their ratings worldwide.

\section{QUESTION II}

\section{IN THE CONTEXT OF THE RECENT CRISIS, HOW DID CRAS BECOME IMPLICATED?}

In view of the fact that CRA assessments of credit quality have, for a number of years, become embedded in international, regional, and domestic regulatory frameworks, how did their pre-eminent position come under challenge, especially with regard to asset-backed securities?

\section{The "originate and distribute" model of banking}

It is widely accepted that the growth of the market for asset-backed securities, such as subprime mortgages and so-called structured products, represents a fundamental shift in the business model utilised by many modern banks. The traditional "originate and hold" model of banking, where banks held loans to maturity (and where, as a result, credit risk was dangerously concentrated), has today given way to the so-called "originate and distribute" model.

Under this model, banks make loans which are "pooled" and then sold on to investors through a process of securitisation. In this way, highly illiquid assets are transformed into more marketable securities. In the case of "simple" securitisation there exists a pooling of reasonably homogenous assets with a given and, generally lower, risk profile. However, more complex securitsations (so-called second-tier and higher-tier securitisations) involve a pool of bank loans being sold by the bank (as the "originator") to a bankruptcy remote, off-balance sheet special purpose vehicle (SPV). Since the SPV is not a subsidiary of the bank, it does not appear as part of the bank's consolidated accounts (hence off-balance sheet). Moreover, in view of the fact that the SPV is a separate legal entity, the originator is not legally responsible for its obligations.

A primary motivation behind the use of such structured investment vehicles by banks is to avoid regulatory requirements under which they must ordinarily operate, such as minimal capital requirements and liquidity requirements, as well as other traditional constraints by way of reporting and governance obligations.

Having purchased the pool of bank loans/assets, the SPV is then entitled to the interest payments and the principal sum made by the original borrowers. In order to pay the bank for the loan pool, the SPV parcels together these newly acquired loans into securities which are backed by the cash flows (interest and principal payments) from the parcelled loans (hence the term asset-backed securities). Additional finance is typically secured via short term loans, which makes such vehicles highly vulnerable in the event that loan providers lose confidence. Acting on behalf of the SPV and in return for a fee, the originating bank collects the stream of cash flows associated with the re-packaged assets.

In an attempt to make the newly issued asset-backed securities more attractive to investors, various tranches are 
issued, each with different risk-return characteristics. In the event that losses occur, these are, in effect, apportioned on a sliding scale - typically "senior", "mezzanine", and "equity" - according to investors' appetite for risk (with "equity" trances bearing the most risk). In other words there exists a "credit cushion" whereby the pool of mortgages or other securitised assets are structured so as to absorb a certain amount of losses before they are felt by those further up the chain.

\section{The role of CRAs}

CRAs occupied a critical role in facilitating the spectacular growth of the market for structured products. Much of this was to do with their supposed superior ability to assess the credit risk associated with complex credit instruments. Interestingly, in January 2008, although there were only 12 triple A-rated companies in the world, there were as many as 64,000 structured finance instruments rated triple $\mathrm{A}$.

Because of the claimed ability of CRAs to decode the special credit risks associated with structured products (a skill upon which their important position within international, regional and national regulatory frameworks was ostensibly predicated), the rating of such securities became an increasingly lucrative and important source of revenue for CRAs, sometimes generating fees that were four and perhaps even five times that which could be earned by rating equivalent sums of traditional bonds.

What is more, issuers also had strong incentives to seek ratings for their structured products based on the same standardised alphabetical scales used to rate more traditional products. With many financial institutions embedding ratings within their operating procedures, or with minimum ratings thresholds contained within investment mandates, issuers were heavily reliant on ratings to maximise the pool of potential purchasers of their securities - a pool which was in fact potentially worldwide. As a result, there was pressure on issuers to secure, and an incentive for rating agencies to award, overinflated ratings.

The meltdown in the market for residential backed mortgage securities, which was triggered by the slump in the US housing market, resulted in an increase in the rate of defaults on subprime loans. This in turn led to a significant reduction in the amount of monthly principal and interest payments derived from the underlying pools of assets (subprime residential mortgages etc). Although the junior tranches were hit first, this resulted in a loss of credit enhancement for the more senior tranches, which in turn precipitated ratings downgrades on a huge scale.

The ultimate effect of these events was a massive loss of confidence in credit ratings for structured finance instruments and vehicles more generally. Moreover, because of the existence of minimum quality thresholds in investor mandates, downgrades also had the effect of triggering through "forced" selling the more widespread problems currently afflicting the global financial markets.

\section{Criticisms of CRAs}

These events spawned a wave of renewed criticism of CRAs, much of which mirrors earlier attacks on the integrity of their operations, and served to intensify the debate about whether and if so how CRAs are to be regulated.

\section{(a) Conflicts of interest}

Firstly, observers again seized on the acute conflicts of interest associated with the "issuer pays" model, whereby both the issuer and the ratings agencies have an economic interest in ensuring the success of the issue: the issuer, in ensuring the sale of its securities; and the CRA - because of scale of fees at stake - in securing lucrative future business from the issuer. In this sense, ratings became almost a matter of negotiation rather than one of arm's length commercial judgment. Concerns about the impartiality of ratings also surfaced where CRAs provided additional advisory services to the issuer (business which CRAs were loath to forego). Conflict of interest problems were also thought to be exacerbated by issuers' willingness to "ratings shop" so as to choose which rating to use based on the preliminary rating provided by the agency's ratings committee.

\section{(b) Flawed models and tardy downgrades}

Secondly, criticism also centred on the methodologies and assumptions used by CRAs to rate structured products. Although CRAs claimed that the meltdown in the structured finance market was "unprecedented", attention focused on the models used by CRAs and criticisms were made that these models failed fully - or even adequately - to reflect the credit risk associated with the innovative financial products to which ratings were assigned.

Linked to this criticism were claims that CRAs were overly reactive to events associated with the implosion in the markets for securities backed by US subprime mortgages - and that they lacked sufficient incentives to downgrade securities in a timely manner.

\section{(c) Lack of accountability}

A third, and final, criticism (again echoing earlier challenges) revolved around a lack of accountability associated with the activities of CRAs. Although pre-crisis is was thought by some that market forces could constrain and legitimize CRA power, it was widely felt that the market for ratings suffered from demonstrable market failures - principally associated with the fact that there are only three major agencies - which were not likely to be self-correcting and which were too important to ignore. What is more, as recent events have all too clearly shown, 
the full costs of the inability of CRAs to assess credit quality accurately are not confined to the parties immediately affected. Rather, they are borne by the whole of society by way of public sector guarantees. These guarantees occur because of the collateral damage which financial collapses are capable of inflicting on a wide range of financial actors, principally banks, and because of the adverse impact which financial sector dislocations have on the "real" economy.

\section{QUESTION III}

\section{IN THE LIGHT OF THE ABOVE CRA SHORTCOMINGS, WHAT HAS THE EU'S RESPONSE BEEN AND TO WHAT EFFECT?}

\section{Regulation (EC) No 1060/2009 on Credit Rating Agencies}

Pre crisis - and even amongst some elements within the EU post-crisis (eg the Committee of European Securities Regulators (CESR)) - opinion was heavily against direct regulation of CRAs. Instead, EU authorities almost unanimously favoured market based approaches, supplemented by the use of international Codes, under the auspices of the International Organization of Securities Commissions (IOSCO). However, as the unfolding link between CRA operations and the financial crisis became clearer, and as the political momentum for "something to be done" began to mount, self-regulatory approaches were by-passed in favour of direct regulation. Following a period of consultation, Regulation (EC) No 1060/2009 on Credit Rating Agencies (hereinafter the "CRA Regulation" or the "Regulation") was published on November 17, 2009 and entered into force on December 7, 2009.

\section{Registration and ongoing supervision}

In essence the CRA Regulation introduces a harmonised approach to the regulation of credit rating activities in the EU. It sets out to achieve this by ensuring that agencies issuing ratings that are used for regulatory purposes (eg ratings used to satisfy capital requirements under the CRD) are subject to a system of registration and ongoing supervision, and that they are under an obligation to comply with a comprehensive set of conduct of business provisions governing issues such as:

- independence;

- conflicts of interest,

- employees and analysts;

- methodologies and models;

- outsourcing; and

- disclosure and presentation of information.

In an attempt to address the global aspect of CRA operations (where EU investors invest in companies or financial instruments rated outside the EU, or where, for the purposes of satisfying capital requirements, banks rely upon ratings from outside the EU) the CRA Regulation introduces two regimes: an "endorsement regime" (for more established CRAs); and a "certification regime" (for smaller CRAs).

\section{Endorsement}

The CRA Regulation makes provision for an endorsement regime, whereby CRAs established in the EU, and registered in accordance with the Regulation, may endorse credit ratings issued by CRAs in third (non-EU) countries provided certain conditions are met. Most significantly, the endorsing CRA must demonstrate to its EU regulator that the set of regulations to which the non-EU entity is subject are, in substance, at least as stringent as those provided for under the CRA Regulation (eg measures in relation to independence and conflicts of interests, rating analysts, methodologies and disclosure) (Recital 13 and Art 4(3)). In this way, the EU regime establishes a global benchmark which third (non-EU) country regimes need to meet in order for ratings produced by these regimes to have regulatory effect within the EU. However, according to Art 4(4), a CRA established in the EU and registered in accordance with the Regulation must not use the endorsement regime as a way of circumventing the requirements of the Regulation.

\section{Equivalence and certification based on equivalence}

Furthermore, and with the purpose of catering for smaller CRAs that are deemed not systemically important for the financial stability of the financial markets of one or more Member States, the Regulation establishes a special certification regime for non-EU CRAs which have no presence in the EU (Recital 14; Art 5(1),(2)). The effect of certification is to enable ratings issued by such entities to be used for regulatory purposes by financial institutions within the Community without the need for endorsement. As with the endorsement regime, certain conditions must be met (which are stipulated in Art 5(1)), paramount amongst which is that the Commission has adopted an "equivalence decision" recognising the legal and supervisory framework of that third country as equivalent to the requirements of the Regulation. By itself, a favourable equivalence determination by the Commission does not automatically entitle CRAs from such third countries to issue ratings which can be used for regulatory purposes by financial institutions within the Community. However, pursuant to Art 5(2) non-EU CRAs may, in the first instance, submit an application to CESR for certification provided the relevant conditions as set out in the Regulation are fulfilled.

\section{Implementation of the CRA Regulation and proposed reforms}

Although the CRA Regulation is directly applicable, which means it is binding in its entirety and has legal effect in the UK without needing to be transposed, it also makes provision for national implementation, for example to deal 
with matters such as penalties, enforcement procedures and appeals from registration decisions. In this respect, it has been implemented in the UK by the Credit Rating Agencies Regulations 2010 (SI 2010/906).

Significantly, in June 2009, just a few weeks after the CRA Regulation had been adopted, the European Commission proposed that the supervisory structure for CRAs as envisaged by the Regulation, should be amended in the light of forthcoming structural changes to the EU financial regulation more broadly. These broader structural changes were the result of the recommendations of the De Larosière Report in March 2009. The effect of these changes for CRAs, is that the European Securities Market Authority (ESMA) - a proposed new supervisory authority fashioned from CESR which will be part of a new European supervisory architecture - will have direct responsibility for CRAs. This centralised model, which was envisaged by Recital 51 of the CRA Regulation, will by-pass the need for the more complex "college arrangements" established under the Regulation to facilitate cross-border cooperation and coordination, and will further help to consolidate the supervisory framework for CRAs. Under the new proposal, CRAs will apply to ESMA for registration. In turn, ESMA will monitor on an ongoing basis whether registered CRAs comply with applicable rules as set out in the CRA Regulation. ESMA will also be vested with a full set of supervisory powers (eg information gathering and enforcement powers), albeit that the transfer of some of these to national competent authorities (eg the power to conduct on-site inspections) is foreseen as a possibility. In essence, the claimed benefits of the proposed new centralised arrangements are threefold: first, that it will establish a single point of contact for registered CRAs; secondly, that it will offer the prospect of a more consistent application of the relevant rules to CRAs throughout Europe; and finally, that it will lead to significant efficiency gains as a result of a more stream-lined system of registration and supervision.
The most significant consequence of these changes is that the supervision of CRA activity within the EU will be further centralised.

\section{CONCLUSION}

CRAs have been subject to widespread criticism for their role in the events associated with the market turmoil of 2008. All told, the above outlined reforms - both enacted and proposed - represent a formidable albeit flawed attempt to regulate CRAs: formidable, in the sense that the Regulation and its accompanying reforms provide for a comprehensive and highly centralised set of regulatory controls involving detailed registration requirements and ongoing supervision; flawed, because despite the use of endorsement and certification techniques to reflect the fact that CRA operations are global in scope, the EU's regulatory efforts nevertheless risk being seen as overly protectionist and out of step with international developments elsewhere, in particular the US.

But perhaps the most interesting and significant longer aspect of the EU's regulation of CRAs lies in its proposal that ESMA should supervise CRAs as from January 2011, and the readjustment in the balance of power between ESMA and the various national supervisory authorities that this would bring. Indeed, these centralising arrangements could presage a more widespread and potentially more significant transfer of regulatory powers to the centre in the field of securities regulation more generally.

\section{Dr Harry McVea}

Reader in Law, University of Bristol and Visiting Fellow, Institute of Advanced Legal Studies, University of London

\title{
Articles for Amicus Curiae
}

Amicus Curiae welcomes contributions, which should be accompanied by the name and contact details of the author. The journal publishes articles on a wide variety of issues, ranging from short pieces of 700-1,200 words and longer articles of 4,000 words of so (the upper limit can be extended where appropriate). Articles should be written in an informal style and without footnotes.

\author{
Anyone interested in submitting a piece should email Julian Harris \\ (julian.harris@sas.ac.uk).
}

